\title{
Peripheral metabolism of testosterone during puberty in the male guinea-pig
}

\author{
A. Robert and P. Delost \\ Laboratoire de Physiologie Animale and ERA CNRS d'Endocrinologie du Développement, \\ Université de Clermont, Ensemble Scientifique des Cézeaux, B.P. 45, 63170 Aubière, France
}

\begin{abstract}
Summary. Variations in the metabolic clearance rate and the production rate of testosterone during puberty in the male guinea-pig were established by single injection and constant infusion methods. Similar results were obtained; MCR (1/24 h) increases from Day 20 to Day 70 and then stabilizes between Days 70 and 90 to levels comparable to those of a 6-month-old adult. MCR as $1 / 24 \mathrm{~h} / 100 \mathrm{~g}$ decreases steadily between Days 20 and 60 . The evolution of the testosterone production rate (PR: $\mathrm{ng} / 24 \mathrm{~h}$ ) is characterized by a marked rise between Days 20 and 70, and then a decrease up to Day 90 , continuing until 6 months. PR as ng/24 h/100 g increases between Days 20 and 40, remains stable until Day 70 , then decreases. Testosterone half-life is stable throughout the pubertal period. The rate of conversion of testosterone to androstenedione remains stable except for a rise between Days 50 and 60 . We conclude that the increase in testosterone concentrations during puberty is due to a rise in the production rate and not to a decrease of clearance rate.
\end{abstract}

\section{Introduction}

In the guinea-pig (Robert \& Delost, 1975; Rigaudière, Pelardy, Robert \& Delost, 1976), plasma and testicular androgens rise significantly between Day 16 and Days 50-60, when puberty occurs. During this time, a linear increase occurs in plasma and testicular concentrations of testosterone as well as in body, testis and seminal vesicle weight. Between Days 50-60 and 90, the hormone levels remain stable but the reproductive organs continue to gain weight.

We have now studied the peripheral metabolism of testosterone during the prepubertal and pubertal periods in the guinea-pig by using the single injection or constant infusion of isotopes as described by Tait (1963), Tait \& Burstein (1964) and Gurpide (1972) for man. These authors devised mathematical models to examine the results and calculated the metabolic clearance rate (MCR), the production rate (PR), the conversion rate (CR), and the half-life $\left(t \frac{1}{2}\right)$ of the testosterone. All these values were calculated for the guinea-pig.

\section{Materials and Methods}

\section{Animals}

The study was carried out on male guinea-pigs of the Dunkin-Hartley strain. Groups of 12-20 animals of similar weight were constituted on Days 16, 20,30,40,50,60,70 and 90 of age. Anaesthesia, induced by $2 \%$ chloral $(2 \mathrm{ml} / 100 \mathrm{~g}$ body weight $)$ and atropine $(0.25 \mathrm{ng} / 100 \mathrm{~g})$, was used only for catheterization by the method of Waeldele \& Stoclet (1973). The first catheter was introduced into the right jugular vein for injections or infusions and a second was implanted into the left carotid artery and used for blood sampling. The animals were placed in transparent plastic cages without lids for the administration of the labelled hormones between 09:00 and11:00 h on the 3rd day after catheterization (see Farris, Hurley, Hane \& Forsham, 1969). These methods avoided, as far as possible, any circadian rhythm in the secretion of testosterone and stress due to restraint, such as that used by Free \& Tillson (1973). 


\section{Assays}

Constant infusion. The hormone for infusion $\left(4-6 \mu \mathrm{Ci}\left[1,2,6,7(\mathrm{n})-{ }_{-}^{3} \mathrm{H}\right]\right.$ testosterone (sp. act. 40-60 Ci/ mmol: Radiochemical Centre, Amersham, U.K.)) was prepared in $0.9 \%(\mathrm{w} / \mathrm{v}) \mathrm{NaCl}$ solution by adding $0.5 \%(\mathrm{v} / \mathrm{v})$ ethanol. The degree of purity of the hormone was $98 \%$ and the degenerative index was $<1 \%$. The solution of testosterone was introduced into the blood at a constant rate of $0.62 \mathrm{ml} / \mathrm{h}$. Each guinea-pig received $0.5 \mu \mathrm{Ci} / \mathrm{h} / 100 \mathrm{~g}$ and the radioactivity values were constant within 50 min after the beginning of the infusion. To check whether equilibrium had been reached, 4 samples of $250 \mu \mathrm{l}$ were withdrawn every $10 \mathrm{~min}$ after the 50 th minute. The coefficient of variation for these values did not exceed $20 \%$ during equilibrium.

Single injection. About $1 \mu \mathrm{Ci}$ tritiated testosterone $/ 100 \mathrm{~g}$ body weight was injected into the jugular vein. To determine the disappearance curve of the concentration of radioactivity as a function of time, $250 \mu 1$ plasma samples were withdrawn at $30 \mathrm{sec}$ and $1,1 \frac{1}{2}, 2,4,6$ and 8 min after injection. The integration equation of the curve corresponding to a two-compartmental model was calculated on a Hewlett-Packard computer.

\section{Hormone measurements}

Testosterone concentrations for production rate calculations were assayed by gas-liquid chromatography with electron capture detection (tritiated source) on intact animals (Robert \& Delost, 1975). Plasma was extracted with ether $(2 \times 3 \mathrm{ml})$ and the organic phase was decanted and evaporated. Testosterone was separated from androstenedione by silica gel thin-layer chromatography (GH 254) in a solvent system of benzene :methanol $(96: 4 \mathrm{v} / \mathrm{v})$. Testosterone was eluted by means of methanolbenzene and androstenedione by methanol. The radioactivity was measured in a Tricarb scintillation counter (Packard). Losses were calculated by adding an internal standard of $\left[4-{ }^{14} \mathrm{C}\right]$ testosterone. The response was linear for 50 to $200 \mu \mathrm{l}$ plasma. For each quantity, the repeatability was situated between 2 and $3 \%$.

Means and standard error (s.e.m.) were calculated and the significance of the differences was determined by Student's $t$ test.

\section{Results}

\section{Clearance rate of testosterone}

No statistically significant differences were observed between the methods, i.e. constant infusion and injection, and the means were therefore derived from both sets of results to give the curve of MCR evolution during puberty (Table 1 ).

The MCR $(1 / 24 \mathrm{~h})$ had increased by $75 \%(P<0.001)$ from Day 20 to the maximum on Day 70 , which was similar to the values in adult guinea-pigs. When MCR was expressed as $1 / 24 \mathrm{~h} / 100 \mathrm{~g}$ it decreased regularly by $43 \%$ between Days 20 and $60(P<0.001)$, and then fell further to reach adult values.

Table 1. Data (mean \pm s.e.m.) of metabolic clearance rate (MCR), production rate (PR) and conversion rate of testosterone to androstenedione $(\mathrm{A} / \mathrm{T} \times 100)$ in the male guinea-pig during puberty

\begin{tabular}{|c|c|c|c|c|c|c|}
\hline \multirow{2}{*}{$\begin{array}{c}\text { Age } \\
\text { (days) }\end{array}$} & \multirow{2}{*}{$\begin{array}{c}\text { No. of } \\
\text { animals }\end{array}$} & \multicolumn{2}{|c|}{ MCR } & \multicolumn{2}{|c|}{ PR } & \multirow[b]{2}{*}{$\mathrm{A} / \mathrm{T} \times 100$} \\
\hline & & $1 / 24 h$ & $1 / 24 h_{100 g^{-1}}$ & $\mathrm{ng} / 24 \mathrm{~h}$ & $\mathrm{ng} / 24 \mathrm{~h} 100 \mathrm{~g}^{-1}$ & \\
\hline 20 & 11 & $29 \cdot 1 \pm 1.9$ & $12 \cdot 4 \pm 1 \cdot 3$ & $56.0 \pm 5.9$ & $24 \cdot 9 \pm 2 \cdot 7$ & $22 \cdot 0 \pm 3 \cdot 1$ \\
\hline 30 & 20 & $34 \cdot 4 \pm 1 \cdot 3$ & $10.9 \pm 0.3$ & $61.9 \pm 2.4$ & $19 \cdot 7 \pm 0.6$ & $17 \cdot 3 \pm 2 \cdot 5$ \\
\hline 40 & 12 & $35.7 \pm 3.8$ & $9.9 \pm 0.8$ & $154 \cdot 6 \pm 1 \cdot 6$ & $40 \cdot 1 \pm 3 \cdot 3$ & $20 \cdot 4 \pm 2.4$ \\
\hline 50 & 19 & $40.6 \pm 1.8$ & $9 \cdot 1 \pm 1.6$ & $189.8 \pm 9.8$ & $43 \cdot 3 \pm 1 \cdot 9$ & $15 \cdot 1 \pm 1 \cdot 7$ \\
\hline 60 & 16 & $42.9 \pm 1.3$ & $7 \cdot 1 \pm 0.4$ & $262 \cdot 4 \pm 14 \cdot 6$ & $44.9 \pm 2 \cdot 5$ & $28.4 \pm 3.9$ \\
\hline 70 & 14 & $50 \cdot 8 \pm 4 \cdot 7$ & $7.4 \pm 0.7$ & $289 \cdot 8 \pm 2 \cdot 7$ & $42 \cdot 2 \pm 4 \cdot 4$ & $17 \cdot 1 \pm 3 \cdot 4$ \\
\hline 90 & 12 & $43.2 \pm 1.7$ & $6 \cdot 3 \pm 0.2$ & $210 \cdot 4 \pm 8 \cdot 2$ & $30 \cdot 9 \pm 1 \cdot 0$ & $15 \cdot 1 \pm 3 \cdot 4$ \\
\hline 180 & 16 & $49 \cdot 3 \pm 3 \cdot 0$ & $5.3 \pm 0.3$ & $176.6 \pm 9.0$ & $18.6 \pm 0.9$ & $14.0 \pm 1.9$ \\
\hline
\end{tabular}




\section{Production rate of testosterone}

The concentrations of testosterone $(\mathrm{ng} / 10 \mathrm{ml})$ used to calculate the rate of production of testosterone were assessed previously on untested groups of animals (15/group): the values were $10 \cdot 1 \pm 3 \cdot 3$ at 20 days, $18 \cdot 0 \pm 3 \cdot 5$ at 30 days, $40 \cdot 5 \pm 3 \cdot 0$ at 40 days, $49 \cdot 1 \pm 8 \cdot 2$ at 50 days, $61 \cdot 0 \pm 8 \cdot 0$ at 60 days, $57 \cdot 0 \pm 8 \cdot 0$ at 70 days, $48 \cdot 7 \pm 5 \cdot 0$ at 90 days and $35 \cdot 0 \pm 4.9$ at 180 days. The PR of testosterone in $\mathrm{ng} / 24 \mathrm{~h}$ increased by $418 \%(P<0.001)$ between Days 20 and 70 and then decreased by $27 \%$ $(P<0.001)$ between Days 70 and 90 and by Day 180 (Table 1$)$. When PR was estimated in $\mathrm{ng} / 24 \mathrm{~h} / 100 \mathrm{~g}$, there was a rise of $103 \%(P<0.001)$ between Days 30 and 40 ; the PR then remained stable until Day 70 before decreasing.

\section{Conversion rate of testosterone to androstenedione}

The $\mathrm{A} / \mathrm{T} \times 100$ ratio changed in the course of puberty (Table 1 ): the values were relatively stable between Days 20 and 50, then there was an increase of $88 \%(0.01<P<0.001)$ by Day 60 , followed by a $40 \%$ decrease $(0.02<P<0.05)$ between Days 60 and 70 . The adult values at 90 and 180 days of age were similar to those at 70 days.

\section{Half-life $\left(t \frac{1}{2}\right)$ of testosterone}

Half-life, estimated in minutes, underwent only slight changes between Days 20 and 90: it was $6.9 \pm 0.9$ at 20 days, $7.7 \pm 0.6$ at 30 days, $7.4 \pm 0.7$ at 50 days, $6.1 \pm 1.5$ at 60 days and $8.3 \pm 0.7$ at 90 days.

\section{Discussion}

The pubertal period in the guinea-pig can be divided into two parts (Robert et al., 1975; Rigaudière et al., 1976): a prepubertal period, from Days 16 to 60 during which a linear increase in plasma testosterone concentration occurs according to the regression equation $y=1.08 x+4.7(r=0.96$; $n=60$ ), and a postpubertal period from Days 60 to 90 when the levels of testosterone remain stable. The present results show that the evolution of MCR $(1 / 24 \mathrm{~h})$ and testosterone production rate during puberty also take place in two stages. The linear change in testosterone MCR $(1 / 24 \mathrm{~h})$ between Days 20 and 70 is represented by the regression $y=2.41 x+4.91(r=0.96 ; n=50)$. The evolution of the MCR according to body weight is also linear; e.g. between 150 and $700 \mathrm{~g}$ body weight, the MCR change $(1 / 24 \mathrm{~h})$ follows the regression $y=0.06 x+11.07(r=0.74 ; n=50)$. The MCR is stable between Day 70 and Month 6, and seems to remain at this level to the end of life (Jarrige, Lac, Robert \& Rigaudière, $1975)$. The $P R$ also varies in two stages as puberty occurs; the first is a prepubertal period marked by a linear increase between Days 20 and 70 and the regression equation is $y=0 \cdot 18 x+13 \cdot 32(r=0 \cdot 96 ; n=50)$. The second stage is the postpubertal period and is characterized by a decrease of PR between Days 70 and 90, which continues to the age of 6 months. The rise in the production rate of testosterone during the prepubertal period is concomitant with those occurring in plasma and testicular concentrations of testosterone. The rise in the production rate of testosterone during puberty may be regarded as the evidence of a revival of activity on the part of the Leydig cells, but this has not been studied in the pubertal guinea-pig. A rise in LH has not been observed in the plasma of guinea-pigs at puberty (Donovan et al., 1975).

The increase in concentration of plasma testosterone during puberty is correlated with a rise in the rate of production of testosterone and not with a decrease in the MCR and it is therefore necessary to examine the various factors that may exert an influence upon the MCR. Among these are the ratio of free testosterone:total testosterone. The lack of steroid-binding protein (SBP) in the guinea-pig (Corvol \& Bardin, 1973) implies that this ratio is constant and might also account for the high MCR of testosterone because species which are known to have SBP also have a low testosterone MCR, e.g. rabbit (Mahoudeau, Corvol \& Bricaire, 1973) and man (Corvol \& Bardin, 1973). Conversely in species not having such specific proteins, MCR is higher, e.g. dog (Chapdelaine, 1969; Tremblay, Kowarski, Park \& Migeon, 1972) and rat (Lee, Bird \& Clark, 1975). It is to these species that the guinea-pig seems to be allied because it seems impossible to ascribe variations in MCR and PR at puberty to changes in SBP values. 
A gradual adaptation of hepatic tissues to hormonal catabolism might be considered to influence MCR, as it does in the rat (Scott \& Taurig, 1973). These workers suggested that this phenomenon would develop as the volume of hormone distribution increases but half-life remains stable. This is indeed what seems to be indicated by the evolution of $t \frac{1}{2}$ in the guinea-pig, which does not change throughout puberty.

The rise in plasma concentration and production rate of testosterone might be linked with a change in enzyme activity, particularly in the $17 \beta$-hydroxysteroid dehydrogenase activity in the testis (Kaguera \& Toki, 1971). During the prepubertal period in the guinea-pig, an inversion of the androstenedione:testosterone ratio in the plasma has been reported, and this can be interpreted as an active conversion of androstenedione into testosterone (Robert \& Delost, 1975). The fact that the evolution of the rate of conversion of testosterone into androstenedione reaches maximal values at Day 60 seems to confirm the fact that this enzymic equipment undergoes significant changes in the course of sexual maturation.

Thus, in guinea-pig, it may be concluded that the increase in plasma concentration of testosterone during puberty between Days 20 and 70 of life results from a rise in the rate of production and not from a decrease in MCR, which also rises in the same time. MCR evolution seems to indicate that the variations are due to some modifications of enzyme actions and not to those occurring at the level of testosterone protein binding. These various observations lead us to conclude that, in the guinea-pig, hormonal puberty occurs at about Day 70 of postnatal life.

\section{References}

Chapdelaine, A. (1969) Sites in vivo extraction and interconversion of testosterone and androstenedione in dogs. J. clin. Invest. 48, 2063-2073.

Corvol, P. \& Bardin, C. W. (1973) Species distribution of testosterone binding-globulin. Biol. Reprod. $\mathbf{8}$, 277-282.

Donovan, B. T., ter HaAR, M. B., Lockhart, A. N., Mackinnon, P. C. B., Mattock, J. M. \& Peddie, M. J. (1975) Changes in concentrations of luteinizing hormone in plasma during development in the guinea-pig. J. Endocr. 64, 511-520.

Fariss, B. L., Hurley, T. J., Hane, S. \& Forsham, P. (1969) Reduction of testicular testosterone in rat by ether anaesthesia. Endocrinology 84, 940-942.

Free, M. J. \& TILlson, S. A. (1973) Secretion rate of testicular steroids in the conscious and halothane anesthetized rat. Endocrinology 93, 874-879.

GURPIDE, E. (1972) Mathematical analysis for the interpretation of in vivo tracer infusion experiments. Acta endocr., Copenh., Suppl. 158, 26-43.

Jarrige, J. F., Lac, G., Robert, A. \& Rigaudière, N. (1975) Taux de clearance mètabolique de la testostèrone chez le Cobaye. J. Physiol., Paris 71, 290A-291A.

KAgUeRA, E. \& ToKI, S. (1971) New aspect of guinea-pig $17 \beta$-hydroxysteroid dehydrogenase. Life Sciences 10, 469-474.

Lee, D. K. H., Bird, C. E. \& Clark, A. F. (1975) In vivo metabolism of ${ }^{3} \mathrm{H}$-testosterone in adult rat male: effect of estrogen administration. Steroids 26, 137-147.

Mahoudeau, J. A., Corvol, P. L. \& Bricaire, M. (1973) Rabbit testosterone-binding globulin. II.
Effect of androgen metabolism in vivo. Endocrinology 92, 1120-1125.

Rigaudière, N., Pelardy, G., Robert, A. \& Delost, P. (1976) Changes in the concentrations of testosterone and androstenedione in the plasma and testis of the guinea-pig from birth to death. $J$. Reprod. Fert. 48, 291-300.

Robert, A. \& Delost, P. (1975) Evolution des teneurs plasmatiques et testiculaires en testostèrone et en androstènedione au cours de la pubertè chez le Cobaye. C. r. hebd. Séanc. Acad. Sci., Paris D 281, $555-558$.

ScotT, J. N. \& TAurig, M. M. (1973) Radioactivity in reproductive organs and the liver of neonatal and adult rats following $3 \mathrm{H}$-testosterone administration. Biol. Neonate 33, 346-350.

Talr, J. F. (1963) Review. The use of isotopic steroids for the measurement of production rates in vivo. J. clin. Endocr. Metab. 23, 1285-1297

TAIT, J. F. \& BursteIN, S. (1964) In vivo studies of steroid dynamics in man. In The Hormones, Vol. 5, pp. 441557. Eds G. Pincus, K. W. Thimann \& E. B. Astwood. Academic Press, New York.

Tremblay, R. R., Kowarski, A., Park, J. J. \& Migeon, C. J. (1972) Blood production rate of dehydrotestosterone in the syndrome of male pseudohermaphrodism with testicular feminisation. $J$. clin. Endocr. Metab. 35, 101-107.

Waeldele, G. \& Stocler, J. C. (1973) Catheterisme permanent de l'aorte thoracique. Mesure de la pression artérielle, injection de substances et prélévements de sang sur l'animal vigile. J. Physiol., Paris 66, 357-366. 